\title{
On the status of Phytopythium kandeliae (Oomycetes, Straminipila)
}

\author{
Marano AV, Jesus AL, de Souza JI, Jerônimo GH and Pires-Zottarelli CLA \\ ${ }^{1}$ Instituto de Botânica, Núcleo de Pesquisa em Micologia, Av. Miguel Stéfano 3687, CEP 04301-012, São Paulo, SP, \\ Brazil.*agosvm@hotmail.com
}

Marano AV, Jesus AL, de Souza JI, Jerônimo GH, Pires-Zottarelli CLA 2014 - On the status of Phytopythium kandeliae (Oomycetes, Straminipila). Mycosphere 5(6), 768-769, Doi 10.5943/mycosphere/5/6/7

\begin{abstract}
Phytopythium kandeliae was recently published as a new combination. The existence of contradictory information about the vouchers CBS 111.91, 112.91 and 113.91 at the CBS-KNAW and the identity of the ex-type specimen is herein clarified.
\end{abstract}

Keywords - isonyms - Phytopythium - voucher specimens

\section{Introduction}

Halophytophthora kandeliae H.H. Ho, S.Y. Hsieh \& H.S. Chang was isolated from submerged leaves of Kandelia candel Druce in Taiwan (Ho et al. 1991). The holotype T0928-5V was deposited as a dried culture at the Institute of Botany, Taipei, Taiwan, while its ex-type culture (ATCC 66501) was deposited at the American Type Culture Collection (USA) together with the voucher specimens ATCC 66502 and 66503. In addition, a subculture of the ex-type (NBRC 326200) was deposited at the National Institute of Technology and Evaluation (Japan). Three additional specimens (CBS 111.91, 112.91 and 113.91) were deposited at the CBS-KNAW Fungal Biodiversity Centre (Netherlands) by H.A. Chang (unpublished).

Phylogenetic studies that placed $H$. kandeliae in the Phytopythium clade were almost exclusively based on the voucher specimens CBS 111.91 and CBS 113.91 (Bala et al. 2010, Robideau et al. 2011, Nigrelli \& Thines 2013, Marano et al. 2014a). The ex-type strain ATCC 66501 was sequenced as part of the Project "World Phytophthora Collection (WPC)" (strain number WPC 11614), but these sequences were never published or included in phylogenetic studies. Recently, three strains identified as $H$. kandeliae based on morphology and molecular analysis together with the vouchers CBS 111.91 and CBS 113.91 and the sequence of the ex-type were retrieved in the Phytopythium clade (Marano et al. 2014b). At the CBS-KNAW website the vouchers CBS 111.91 and CBS 113.91 appeared as an undescribed species of Phytopythium, while the voucher CBS 112.91 appeared as the ex-type of $H$. kandeliae, but has been recently sequenced and recognised as a new species of Salisapilia (A.W.A.M de Cock, personal communication).

Thines (2014) transferred H. kandeliae to Phytopythium and some months later Marano et al. (2014b) proposed the same combination, which is an invalid isonym (Art. 6.3, Note 2, McNeill et al. 2012). 


\section{Nomenclature}

Phytopythium kandeliae (H.H. Ho, H.S. Chang \& S.Y. Hsieh) Thines, European Journal of Plant Pathology 138: 435, Jan 2014.

$\equiv$ Halophytophthora kandeliae H.H. Ho, H.S. Chang \& S.Y. Hsieh, Mycologia 83(4): 419, 1991.

"Halophytophthora kandelii" H.H. Ho, S.Y. Hsieh \& H.S. Chang, Fourth International Mycological Congress Abstracts (Regensburg): 125, 1990, nom. inval. (no Latin).

"Phytopythium kandeliae" Marano, A.L. Jesus \& Pires-Zottar., Mycosphere 5(4): 518, Aug 2014, nom. inval. (later isonym).

\section{Acknowledgements}

We are indebted to the editor and especially to Dr. Shaun Pennycook for their constructive comments, which helped us to substantially improve the manuscript. We thank Dr. Arthur W.A.M de Cock for providing valuable information regarding the voucher specimens deposited at the CBSKNAW. We also wish to thank CAPES (Coordenação de Aperfeiçoamento de Pessoal de Nível Superior) for the fellowship and support given to AV Marano ("Ciência Sem Fronteiras" Program, "Atração de Jovens Talentos" DRI- CAPES Process No. 006/2012) and FAPESP for the fellowship given to AL Jesus (Process No. 2013/01409-0), and for the financial support given to CLA PiresZottarelli (Process No. 12/50222-7). CNPq (Conselho Nacional de Desenvolvimento Científico e Tecnológico) is also acknowledged for the grant given to C. L. A. Pires-Zottarelli (Process No. 304411/2012-4).

\section{References}

Bala K, Robideau GP, Lévesque CA, de Cock AWAM, Abad ZG, Lodhi AM, Shahzad S, Ghaffar A, Coffey MD. 2010 - Phytopythium Abad, de Cock, Bala, Robideau, Lodhi \& Lévesque, gen. nov. and Phytopythium sindhum Lodhi, Shahzad \& Levésque, sp. nov. Persoonia 24, 136137.

CBS-KNAW Fungal Biodiversity Centre. 2014 - http://www.cbs.knaw.nl (accessed 13 Nov 2014).

Ho HH, Chang HS, Hsieh SY. 1991 - Halophytophthora kandeliae: a new marine fungus from Taiwan. Mycologia 83, 419-424.

Marano AV, Jesus AL, Pires-Zottarelli CLA, James TY, Gleason FH, de Souza JI. 2014a Phylogenetic relationships of Pythiales and Peronosporales (Oomycetes, Straminipila) within the "peronosporalean galaxy". In: Gareth Jones EB, Hyde KD, Pang K-L (eds.). Freshwater fungi and fungal like organisms. Berlin: De Gruyter. pp. 177-200.

Marano AV, Jesus AL, de Souza JI, Leaño EM, James TY, Jerônimo GH, de Cock AWAM, PiresZottarelli CLA. 2014b - A new combination in Phytopythium: P. kandeliae (Oomycetes, Straminipila). Mycosphere 5, 510-522.

McNeill J, Barrie FR, Buck WR, Demoulin V, Greuter W, Hawksworth DL, Herendee S, Knapp S, Marhold K, Prado J, Prud'Homme van Reine WF, Smith GF, Wiersema JH. 2012 International Code of Nomenclature for algae, fungi, and plants (Melbourne Code). http://www.iapt-taxon.org/nomen/main.php?page=title

Nigrelli L, Thines M. 2013 - Tropical oomycetes in the German bight: climate warming or overlooked diversity? Fungal Ecology 6, 152-160.

Robideau GP, de Cock AWAM, Coffey MD, Voglmayr H, Brouwer H, Bala K, Chitty DW, Désaulniers N, Eggertson QA, Gachon CMM, Hu CH, Küpper FC, Rintoul TL, Sarhan E, Verstappen ECP, Zhang Y, Bonants PJM, Ristaino JB, Lévesque AC. 2011 - DNA barcoding of oomycetes with cytochrome c oxidase subunit I and internal transcribed spacer. Molecular and Ecological Resources 11, 1002-1011.

Thines M. 2014 - Phylogeny and evolution of plant pathogenic oomycetes - a global overview. European Journal of Plant Pathology 138, 431-447. 